\title{
Pawet Popieliński
}

Instytut Studiów Politycznych PAN

ORCID 0000-0001-7137-813X

\section{Dylematy tożsamościowe młodej generacji mniejszości niemieckiej w województwie opolskim okiem niemieckiej badaczki kultury}

Katharina Schuchardt, Zwischen Berufsfeld und Identitätsangebot. Zum Selbstverständnis der deutschen Minderheit im heutigen Opole/Oppeln, Kieler Studien zur Volkskunde und Kulturgeschichte, Band 13, Waxmann Verlag, Münster 2018, ss. 364.

Katharina Schuchardt studiowała etnologię europejską, ekonomię polityczną i archeologię klasyczną na Uniwersytecie Chrystiana Albrechta w Kilonii. Tytuł magistra ( $\mathrm{Ma}$ gistra Artium) otrzymała w 2011 roku. W następnym roku została wykładowcą na Uniwersytecie Adama Mickiewicza w Poznaniu. W latach 2014-2017 uzyskała stypendium im. Immanuela Kanta, wspierające doktorantów, którzy zajmują się historią i kulturą Niemców w Europie Wschodniej. Stypendium zostało ufundowane przez pełnomocnika rządu federalnego do spraw kultury i mediów (niem. Beauftragte der Bundesregierung für Kultur und Medien). Pracę doktorską, stanowiącą podstawę recenzowanej książki, obroniła na Uniwersytecie w Kilonii. Publikacja została wydana przez niemieckie wydawnictwo Waxmann w Münster w serii Kilońskich Studiów Etnologii i Historii Kultury. Schuchardt od 2017 do 2019 roku była pracownikiem naukowym na wydziale Europejskiej Etnologii Uniwersytetu Kilońskiego. Obecnie jest pracownikiem naukowym w Instytucie Saksońskiej Historii i Antropologii Kulturowej na Uniwersytecie Technicznym w Dreźnie.

Po zmianie społeczno-politycznej w Polsce w 1989 roku, w szczególności w latach dziewięćdziesiątych ubiegłego wieku, mniejszość niemiecka na Górnym Śląsku, w kolebce największych i najliczniejszych zwartych skupisk tej mniejszości narodowej, 
została wielokrotnie przebadana i opisana jako grupa mniejszości narodowej. W Polsce oraz Niemczech powstało wiele socjologicznych i politologicznych artykułów i książek dotyczących problematyki mniejszości niemieckiej na Górnym Śląsku lub w poszczególnych regionach Polski. Starania mniejszości niemieckiej o zapewnienie jej politycznych praw i społecznego uznania zwróciły uwagę badaczy na tę grupę społeczną. Jednak do tej pory tylko dwie monografie, które powstały na podstawie przeprowadzonych badań wśród młodych członków tej mniejszości narodowej, zostały poświęcone życiu młodzieży mniejszości niemieckiej na Górnym Śląsku po 1989 roku. Pierwsza monografia ujmująca tematykę życia społeczno-politycznego tej grupy w aspekcie socjologiczno-politologicznym opublikowana w 2011 roku$^{1}$, została napisana przez autora tej recenzji. Druga monografia to praca kulturoznawcza autorstwa Kathariny Schuchardt, będąca przedmiotem niniejszej recenzji. Ta właśnie publikacja odzwierciedla opinie członków młodej generacji mniejszości niemieckiej. W przeprowadzonych przez autorkę wywiadach narracyjnych (polegają one na stymulacji rozmówcy do swobodnego opowiadania o swoich przeżyciach związanych z uczestnictwem w jakimś wydarzeniu lub wydarzeniach) młodzi ludzie mieli możliwość wypowiedzenia się, co i jak kształtuje ich życie codzienne jako członka mniejszości niemieckiej. Na czym opiera się i jak się rozwija ich przynależność do tej mniejszości narodowej? Co kształtuje i zmienia ich tożsamość w warunkach otoczenia polskiego? Czy organizacje tej mniejszości narodowej spełniają ich oczekiwania pod względem kulturalnym i politycznym? Czy przynależność do tych organizacji wpływa na kształtowanie się ich tożsamości narodowej? Odpowiedzi uzyskane na te pytania stanowiły podstawę analiz przedstawionych w monografii.

Praca jest kulturoznawczym mikrostudium mniejszości niemieckiej na Górnym Śląsku. Dotyczy szczególnie takich zagadnień jak: „mniejszość” i „identyfikacja”. W przypadku tych pojęć autorka opiera się na teorii Stuarta Halla, który stwierdza, że tożsamość jest kształtowana przez zmieniający się świat, w którym społeczeństwa rozdzielają się i rozpadają. Przez cały czas podlegają zmianom². W swojej pracy Schuchardt bada konstrukcję identyfikacji młodych ludzi, członków mniejszości niemieckiej na Górnym Śląsku, na tle aktualnych historyczno-politycznych wydarzeń w Polsce po 1989 roku. W centrum zainteresowania autorki jest zrozumienie młodej generacji mniejszości niemieckiej w wieku 20-35 lat, ukształtowanej przez przełom społeczno-polityczny w 1989 roku w Polsce i procesy europeizacji, która musi znaleźć swoje miejsce w kontekście wielu ofert tożsamości. Na ich tożsamość wpływa także polsko-niemiecka historia (przede wszystkim powstania śląskie, II wojna światowa), kultura pamięci, dziedzictwo kulturowe i zaangażowanie w ruchu mniejszości niemieckiej. Szczególną uwagę Schuchardt poświęciła medialnemu dyskursowi dotyczącemu mniejszości niemieckiej - tożsamości jej członków oraz instytucjom mniejszości niemieckiej i jej aktorom. W centrum uwagi są także obawy, szanse i wyzwania stojące przed mniej-

1 P. Popieliński, Młodzież mniejszości niemieckiej na Górnym Śląsu po 1989 roku. Organizacje, tożsamość narodowa, postawy, przyszłość, Instytut Studiów Politycznych PAN, Warszawa 2011.

2 S. Hall, Kulturelle Identität und Globalisierung, w: K.H. Hörning, R. Winter (red.), Widerspenstige Kulturen. Cultural Studies als Herausforderung, Suhrkamp Taschenbuch Wissenschaft, Frankfurt am Main 1999, s. 393-441. 
szością niemiecką. Z perspektywy nauki o kulturze autorka wyjaśnia złożoność tych zjawisk i ich wpływ na młodą generację mniejszości niemieckiej na Górnym Śląsku. Odpowiada przede wszystkim na ważne pytania: Jak są prowadzone i rozpatrywane dyskursywne sposoby interpretacji tożsamości? Jaką rolę odgrywają międzypokoleniowe doświadczenia i pamięć rodzinna w procesie identyfikacji? Jak praktyki polityczne wpływają na kulturową rzeczywistość mniejszości?

Schuchardt $\mathrm{w}$ swojej pracy stosuje metody zbliżone do socjologicznych, aby móc odpowiedzieć na te i inne pytania. Swoją metodologię oparła na wywiadach (biograficznych) narracyjnych przeprowadzonych z młodymi ludźmi z mniejszości niemieckiej, którzy wychowali się w demokratycznej Polsce po roku 1989 i w dobie wstąpienia Polski do Unii Europejskiej, oraz z ekspertami (młodymi pracownikami i działaczami instytucji i organizacji mniejszości niemieckiej w badanym regionie). Wywiady te były kluczowe dla przeprowadzenia analiz przez autorkę oraz zrozumienia problematyki tożsamościowej poruszanej w książce. Cytowane fragmenty przeprowadzonych wywiadów stanowią znaczną część pracy. Autorka przeprowadziła także głęboką analizę mediów, w szczególności mniejszości niemieckiej (głównie czasopism „Wochenblatt”3 oraz młodzieżowego „Antidotum”"). Korzystała również z polskich i niemieckich źródeł - książek i artykułów naukowych dotyczących mniejszości niemieckiej w Polsce.

Książka ma osiem rozdziałów, a na jej końcu znajduje się obszerny spis źródeł i literatury. Każdy z siedmiu rozdziałów składa się z kilku podrozdziałów, natomiast ostatni, ósmy stanowi rodzaj podsumowania. Pierwszy rozdział wprowadza czytelnika w problematykę podjętą w książce, omawia zastosowaną przez autorkę metodologię i dotychczasowy stan badań nad mniejszością niemiecką na Górnym Śląsku - w Niemczech i Polsce. W rozdziale drugim przedstawiono tło historyczne, ze szczególnym uwzględnieniem pierwszych lat powojennych, całego okresu komunistycznego i transformacji społeczno-politycznej w Polsce po 1989 roku. Czytelnik może poznać syntetycznie ujętą historię mniejszości niemieckiej na tle historii Polski.

Teoretyczna część pracy zawarta jest w rozdziale trzecim. Zostały tu omówione najważniejsze pojęcia i teorie zastosowane przez autorkę. W czwartym rozdziale zostały opisane wykorzystane źródła i zakreślone pole badawcze. Piąty rozdział został poświęcony instytucjonalnemu umiejscowieniu się mniejszości niemieckiej. Autorka omówiła działalność najważniejszych organizacji mniejszości niemieckiej w Opolu i w całym województwie oraz przedstawiła na podstawie przeprowadzonych wywiadów, jak one są spostrzegane przez młodych członków mniejszości niemieckiej, w tym jaki mają wpływ na ich tożsamość. Kolejny szósty rozdział prezentuje działalność środków masowego przekazu mniejszości niemieckiej w kontekście ukazywania i przypominania ważnych dla członków mniejszości niemieckiej wydarzeń historycznych, prezentowania przez media materialnego i niematerialnego dziedzictwa kulturowego Górnego Śląska

\footnotetext{
Ogólnopolskie, największe i najważniejsze czasopismo mniejszości niemieckiej wydawane w Opolu.

4 Jest to czasopismo skierowane do młodzieży i przez nią wydawane. Ten dwujęzyczny kwartalnik jest wydawany od 2004 roku przez Związek Młodzieży Mniejszości Niemieckiej w Rzeczypospolitej Polskiej z siedzibą w Opolu. Tematyka artykułów przygotowywana jest pod kątem młodzieży mniejszości niemieckiej.
} 
oraz kreowania niemieckiej śląskiej tożsamości. Najobszerniejszy, siódmy rozdział został poświęcony wieloaspektowej problematyce tożsamościowej młodych członków mniejszości niemieckiej na Górnym Śląsku. Ósmy rozdział stanowi podsumowanie pracy oraz spojrzenie na przyszłość mniejszości niemieckiej w badanym regionie.

Schuchardt podaje liczbę członków mniejszości niemieckiej na Górnym Śląsku oraz w pozostałych częściach Polski. Słusznie zauważa, że liczebność tej mniejszości nie jest identyfikatorem tożsamości narodowej członków organizacji mniejszości niemieckiej. Dokładnie analizuje ten fakt oraz wyraźnie ukazuje tego przyczyny. Dzięki przeprowadzonym badaniom autorce udało się uchwycić zapatrywania młodych ludzi mniejszości niemieckiej oraz dowiedzieć się, co w rzeczywistości składa się na ich tożsamość, często wielowymiarową, w szczególności co miało i ma na to wpływ. Autorka dostrzega, że granice tożsamości młodych osób są niejasno zarysowane, są po prostu płynne. Natomiast pamięć rodzinna ma znaczny wpływ na ich odrębność od polskich rówieśników, co ma większe lub mniejsze przełożenie na poczucie tożsamości. Jednak proces identyfikacji jest często bardzo złożony i z tego powodu młodzi ludzie mają problemy ze swoją tożsamością.

Praca jest ciekawa i oryginalna. Można powiedzieć, że jest pionierska w niemieckim świecie naukowym. Jest bardzo ważnym spojrzeniem kulturoznawczym na mniejszość niemiecką żyjącą w naszym kraju. Wraz ze wspomnianą wyżej monografią autora tych słów, stanowi polsko-niemieckie interdyscyplinarne, kompleksowe spojrzenie badawcze na problematykę współczesnej młodej generacji mniejszości niemieckiej na Górnym Śląsku. Gorąco zachęcam do przeczytania tej ważnej publikacji wszystkich zainteresowanych problematyką mniejszości niemieckiej w Polsce oraz osoby interesujące się tym, jak historia oraz pamięć rodzinna wpływają na tożsamość młodego człowieka. 